OPEN ACCESS

Edited by:

Nicolas Urbina-Cardona, Pontifical Javeriana University,

Colombia

Reviewed by:

Martha Patricia Ramírez-Pinilla, Universidad Industrial de Santander,

Colombia

Amaël Borzée,

Nanjing Forestry University, China

*Correspondence: George C. Brooks boa10gb@vt.edu

Specialty section:

This article was submitted to

Conservation and Restoration Ecology,

a section of the journal

Frontiers in Ecology and Evolution

Received: 11 November 2021

Accepted: 28 January 2022

Published: 22 February 2022

Citation:

Brooks GC and Kindsvater HK (2022) Early Development Drives Variation in Amphibian Vulnerability

to Global Change.

Front. Ecol. Evol. 10:813414. doi: 10.3389/fevo.2022.813414

\section{Early Development Drives Variation in Amphibian Vulnerability to Global Change}

\author{
George C. Brooks* and Holly K. Kindsvater \\ Department of Fish and Wildlife Conservation, Virginia Tech, Blacksburg, VA, United States
}

Understanding how natural selection determines species' life histories can reveal their resilience or sensitivity to anthropogenic changes. For example, the safe harbor hypothesis posits that natural selection will favor life histories that maximize the time spent in the safest life stages; a second theoretical prediction suggests that species with complex life histories will maximize the growth potential of a life stage relative to its safety. Amphibians exhibit complex life histories, with a diversity of developmental strategies occurring across taxa. Many strategies involve the complete elimination of a particular life stage, and thus provide an excellent opportunity to evaluate the main tenets of the safe harbor hypothesis and understand the consequences of this developmental variation for conservation of threatened amphibians. We develop a general framework for understanding developmental life histories of amphibians - including the special cases of paedomorphism, direct development, and viviparity - based on the relative growth potential and safety offered by aquatic and terrestrial habitat, which we tested using a global trait database. We then compare the IUCN Red List status of species differing in developmental mode, revealing that most fully aquatic species and species with an aquatic larval stage are currently of Least Concern, despite the fact that freshwater habitats are being lost at a much faster rate compared with terrestrial ecosystems. The higher proportion of direct developing and viviparous species that are threatened can be attributed to their smaller ranges, the fact that they are more likely to be found in rainforest habitats, and their relatively slow life histories. We conclude that an amphibian's developmental mode reflects the relative costs and benefits of different habitats, and that this could contribute to the resilience or vulnerability of amphibians to future anthropogenic change.

Keywords: IUCN Red List, life histories, paedomorphosis, viviparity, safe harbor hypothesis, direct development

\section{INTRODUCTION}

Amphibians are known both for their diversity of life histories and for the alarming fact that a greater proportion of amphibian species are threatened with extinction than any other vertebrate group (Duellman, 1989; Stuart et al., 2004; Wells, 2007; Hoffmann et al., 2010; IUCN, 2021). Previous work has addressed the relative vulnerability of amphibian taxa with different life histories 
to anthropogenic threats, including climate change, disease, and habitat loss (Becker and Loyola, 2008; Loyola et al., 2008; Becker et al., 2010; Lourenço-de-Moraes et al., 2019). But the unique diversity of amphibian life cycles has not been integrated into standard indices of intrinsic productivity that are frequently used to characterize extinction (Hutchings et al., 2012; Foden et al., 2013; Zhao et al., 2018; He et al., 2021).

The strategies that amphibians have evolved in response to different ecological pressures, given developmental constraints in each lineage, offer a unique window into how species are likely to cope with ongoing environmental change arising from human influences. Although a life history that spans both aquatic and terrestrial environments is most common in amphibians, there are notable exceptions where a species has evolved to specialize on one habitat or the other, and the origin of this diversity in life cycles is not fully understood (Istock, 1967; ten Brink et al., 2019). There are numerous independent examples across the three amphibian orders where a particular developmental stage has been completely omitted, offering a rich opportunity for comparative study (Salthe, 1969; Salthe and Duellman, 1973; Duellman, 1989; Kupfer et al., 2016). Direct development has arisen independently in frogs, salamanders, and caecilians, and involves eliminating the aquatic larval stage in favor of terrestrial egg deposition; progeny complete metamorphosis within the egg (Wells, 2007; Kupfer et al., 2016; Lion et al., 2019). At the opposite end of the spectrum, several salamander lineages exhibit paedomorphosis, remaining fully aquatic throughout life.

The origin and maintenance of these diverse developmental modes in amphibians can be understood in the context of different risk-reward trade-offs experienced in aquatic and terrestrial habitats. The amount of time each species spends in each life stage - which may, at its extreme, mean an entirely aquatic or entirely terrestrial life history - reflects the evolutionary conditions that have generated the remarkable diversity of life histories in amphibians (Werner, 1986; Duellman, 1989). As we will discuss, aquatic habitats can be ephemeral or predictable, risky or safe, and nutritionally rich or poor, relative to their adjacent terrestrial habitats. Here, we argue that understanding the ecological and evolutionary forces that have shaped the life-history diversity of the three amphibian orders offers new insight into differences among species in their risk of extinction.

In this paper we propose a framework based on classic theory to predict how selective forces have shaped the diversity of amphibian life histories, which can generate novel insights into their vulnerability to global change. We highlight disparities in the IUCN Red List status among species with different developmental modes, and that species which have presumably evolved to increase the relative safety of early life stages are more likely to be categorized as threatened. We then explore the connection between developmental mode, species range size, biogeography, and intrinsic sensitivity to anthropogenic threats. Our framework is the first to incorporate the complexity of the full spectrum of amphibian life histories when assessing their relative extinction risk by including their exposure to different threats in different habitats. We suggest this approach can inform global conservation efforts, raise unanswered questions regarding amphibian reproductive strategies, and prioritize future research directions.

\section{A FRAMEWORK FOR PREDICTING HOW SELECTIVE FORCES SHAPE AMPHIBIAN LIFE HISTORIES}

The strategy selection system assumes life-history strategies are shaped by particular characteristics of the environment (Southwood, 1988). The overall strategy of an organism is optimized in a given environment by selective forces operating on a suite of fitness-related traits (Southwood, 1988; Roff, 2002). Abiotic and biotic pressures experienced in a given environment will determine the optimal lifehistory strategy in that environment, and anthropogenic change that alters abiotic and biotic conditions could lead to the evolution of new life-history strategies (which may include shifts to different environments; ten Brink et al., 2020), and/or population declines and extinction (Figure 1). For species with complex life cycles the relative likelihood of these outcomes is dependent upon (1) the strength of phylogenetic inertia, (2) the extent and rapidity of environmental change, and (3) the relative impact of alterations to the habitats utilized by each life stage.

The typical amphibian life cycle consists of a gelatinous egg, deposited in the water, an aquatic larval stage, and a terrestrial adult form following metamorphosis (Duellman and Trueb, 1994). Shine's safe harbor hypothesis posits that natural selection will favor life histories that maximize the time spent in the safest life stages (Shine, 1978). Larger eggs, with correspondingly longer development times, are affordable only when their survival is relatively high (Sih and Moore, 1993; Jørgensen et al., 2011). The safe harbor hypothesis suggests that parental care increases egg survival (via nest attendance or egg guarding) above the survival of a small hatchling, and, therefore, egg size will increase in populations with parental care, decreasing the duration of subsequent, higher risk stages (Wilbur, 1977a; Sargent et al., 1987; Nussbaum and Schultz, 1989; Kolm and Ahnesjö, 2005; Summers et al., 2006, 2007; Schulte et al., 2020). In the absence of parental care, egg safety is predominantly controlled via egg-deposition site (Petranka and Petranka, 1981; Petranka, 1990; Shine and Harlow, 1996; Mitchell, 2002; Martin and Carter, 2013; McKeon and Summers, 2013). Consistent with the theory, viviparity (the retention of offspring in utero) is more prevalent in regions where external eggs would experience lethally high nest temperatures, or cold climates that would slow offspring development (Shine et al., 2003; Ma et al., 2018), and high predation environments can trigger early hatching in several amphibian species (Warkentin, 2011).

Nussbaum (1987) challenged the safe harbor hypothesis by suggesting egg size in amphibians is determined by bottom-up (food availability) as opposed to top-down (predation) forces, and parental care in stream salamanders reflects a consequence of large eggs, rather than the reverse. The contrasting effects 


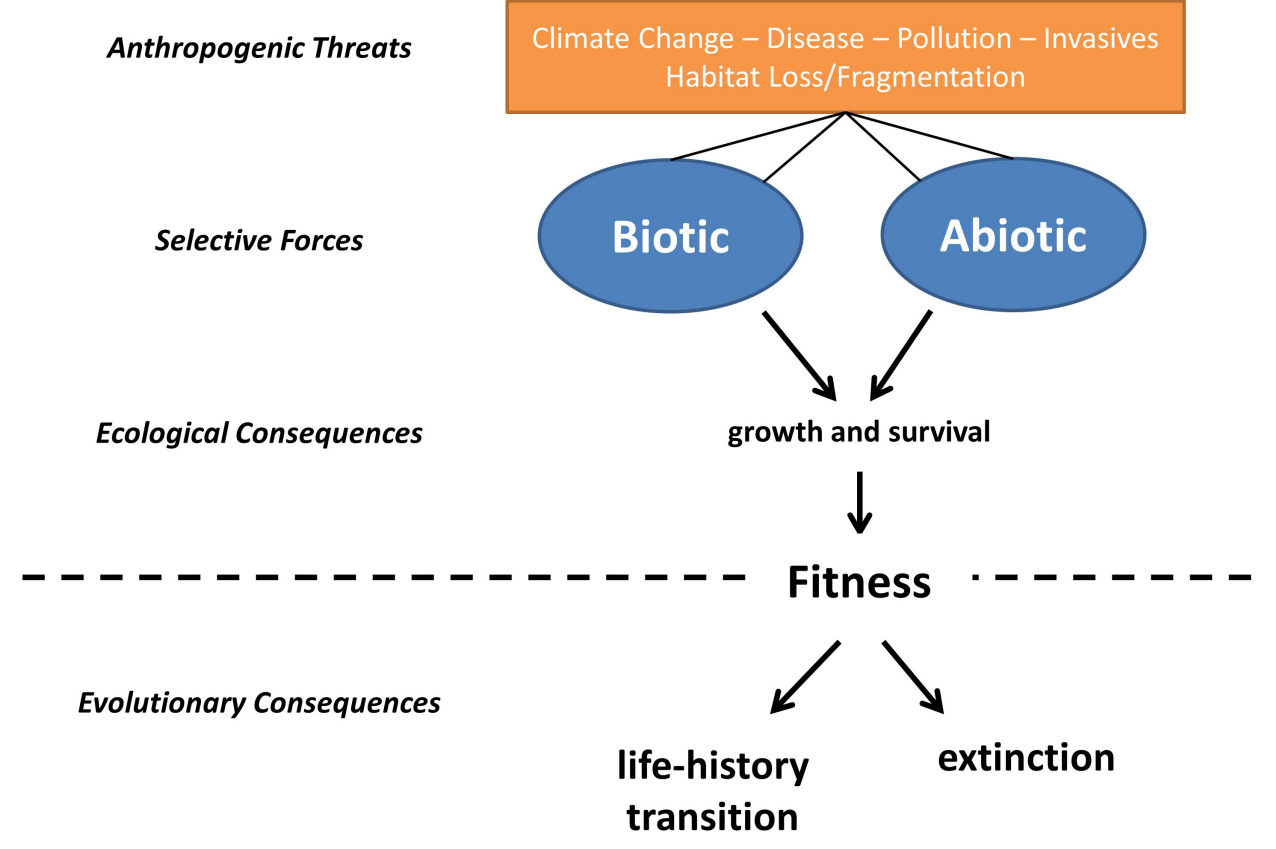

FIGURE 1 | The predicted consequences of anthropogenic stressors on the selection of life-history strategies, adapted from Southwood (1988). The strategy selection system assumes life history strategies are shaped by particular characteristics of a given environment, such that if anthropogenic change alters the abiotic and biotic pressures experienced in that environment, a new optimal life-history strategy will emerge. In the context of amphibian life-histories, changes that disproportionately impact aquatic or terrestrial environments will select for the elimination of the aquatic or terrestrial phase in a life-cycle and/or render species with particular life histories more vulnerable to extinction.

that resource availability and predation pressure exert on life histories has been well established (Werner and Gilliam, 1984; Berrigan and Charnov, 1994; Perrin, 1995; Sevenster, 1995; Abrams and Rowe, 1996; Arendt and Wilson, 1999; Pepin et al., 2003; Urban, 2007, 2008). Yet ultimately, a combination of topdown and bottom-up effects shape an organism's life history, making it challenging to parse out the relative contributions of each selective force (Hutchings, 1993; Stamps, 2007; Dmitriew, 2011; Fiksen and Jørgensen, 2011; ten Brink et al., 2019, 2020).

The separation of life stages among habitats can lead to differences in the risk and fitness payoff (in terms of survival or reproduction) in each stage (Werner et al., 1983). In certain instances, benefits conferred via increased growth (g) justify spending more time in a dangerous life-stage, whilst in others, high predation risk $(\mu)$ will favor strategies that opt for slower growth in safer habitats (Werner and Hall, 1988; Lima and Dill, 1990; Ludwig and Rowe, 1990; Skelly and Werner, 1990; Rowe and Ludwig, 1991; Werner and Anholt, 1993; Relyea, 2001; Sih et al., 2004). The ratio $\mu / g$ has been used to predict transitions among life stages in different contexts (Werner et al., 1983). This ratio has been used to explain the classic amphibian lifecycle using such a risk/reward trade-off, whereby food is more abundant in water, but predation risk is likely to be higher (Wilbur and Collins, 1973; Werner, 1986), such that individuals prioritize growth in the early stages of life and survival postmetamorphosis. Metamorphosis is predicted to occur therefore, when the growth benefits no longer outweigh the mortality costs of remaining in the water (Wilbur, 1980; Werner, 1986; ten
Brink et al., 2020). Intuitively this transition tends to coincide with maturity when resources start to be diverted away from growth and allocated toward reproduction, but this relationship appears somewhat flexible (Rowe and Ludwig, 1991). We propose combining this insight with Shine's original hypothesis by considering the quality of the harbor not just by its relative safety, but also by its growth potential.

\section{VARIATION WITHIN THE CLASSIC AMPHIBIAN LIFE-CYCLE IS CONSISTENT WITH THEORY}

The duration of the terrestrial stage relative to the aquatic stage varies considerably across amphibian taxa (Werner, 1986; Duellman, 1989). Differences between species emerge as a result of variation in the pressures experienced by aquatic larvae relative to the terrestrial environment they will subsequently occupy (McKeon and Summers, 2013). Amphibians that breed in lentic and lotic waterbodies exhibit consistent differences in egg size, larval morphology, and larval duration; differences predominantly driven by the predator communities and productivity/resource availability of each habitat (Salthe, 1969; Summers et al., 2007; Wells, 2007; Davenport and Summers, 2010). The reliability of waterbodies (permanent vs ephemeral) used by amphibians for breeding will also contribute to the relative safety of the aquatic environment, and thus impact reproductive strategy and larval 
traits (Semlitsch and Wilbur, 1988). If aquatic environments offer reduced mortality risk and high growth potential relative to the terrestrial surroundings, the aquatic stage will be long; in risky, resource-poor aquatic environments, the larval stage will be brief.

Many amphibians breed in ephemeral waterbodies, and are thus precluded from an extended larval duration (Wilbur and Collins, 1973; Werner, 1986; Wells, 2007). The absence of predatory fish can result in reduced larval mortality but the small size of most ephemeral waterbodies results in high levels of competition. Within populations, the timing and size at metamorphosis can vary due to competition and densitydependent growth rates (Wilbur and Collins, 1973; Wilbur, 1977b, 1980; Rowe and Ludwig, 1991). The detrimental effects of crowding become more pronounced as water levels recede and drought can result in $100 \%$ mortality if waterbodies dry out before larvae reach sizes necessary for metamorphosis (e.g., Taylor et al., 2006).

In ephemeral wetlands, the duration of the wet periods can be short and/or unpredictable, shaping the life histories of amphibians that breed exclusively in them. The larvae of such species occupy an environment with an intense disturbance regime, akin to ruderal plant species in Grime's life-history triangle (Grime, 1977), or opportunistic species in similar frameworks for categorizing fish life histories (Figure 2; Winemiller and Rose, 1992). Amphibian species in ephemeral habitats typically show rapid growth and development in order to exploit the temporary conditions (Abrams and Rowe, 1996; Altwegg, 2002; Rudolf and Rödel, 2007). Growth and development rates are also known to be extremely plastic in these species, responding to predation threats, food availability, the strength of intraspecific competition, and pond drying rates (Wilbur and Collins, 1973; Wilbur, 1977b, 1980; Werner and Gilliam, 1984; Semlitsch and Wilbur, 1988; Rowe and Ludwig, 1991; Arendt and Wilson, 1999; Urban, 2007, 2008; Dmitriew, 2011).
Whilst the larvae of ephemeral pond breeders all adopt similar strategies, adult traits differ across amphibian clades. As a rule, ephemeral pond-breeding frogs exhibit short life-spans, large clutch sizes, and high dispersal rates. These species overcome the unpredictability of larval habitats by selecting breeding locations according to environmental conditions, in line with an opportunistic or episodic strategy. Salamanders and caecilians in contrast, exhibit traits more in line with stress-tolerant or competitive strategies as adults. As the unpredictability of larval habitat increases, salamanders tend towards longer lifespans that incorporate relatively low annual reproductive investment and multiple breeding attempts. Such a strategy is possible owing to their fossorial existence following metamorphosis and the stability of their underground retreats. The reduced dispersal abilities of salamanders and caecilians compared with frogs and toads may help to explain the relative proclivity of these clades to evolve direct development, whereby eggs are deposited terrestrially and hatch into miniature adults. Without the ability to disperse among breeding locations when conditions at a given site are unsuitable, many have evolved a life history that omits the aquatic stage entirely (Wilbur, 1980; Martin and Carter, 2013). More generally, when the risk-reward trade-off is perpetually favorable in one environment, direct development or paedomorphic strategies will emerge (Figure 3).

\section{DEVIATIONS FROM THE CLASSIC AMPHIBIAN LIFE CYCLE ARE CONSISTENT WITH THEORY}

Most salamanders and caecilians deposit their eggs terrestrially (Wake and Hanken, 2004). Although predation rates are generally thought to be higher in aquatic environments, terrestrial eggs will only achieve higher survival rates compared with aquatic eggs if they are not at risk of desiccation
A

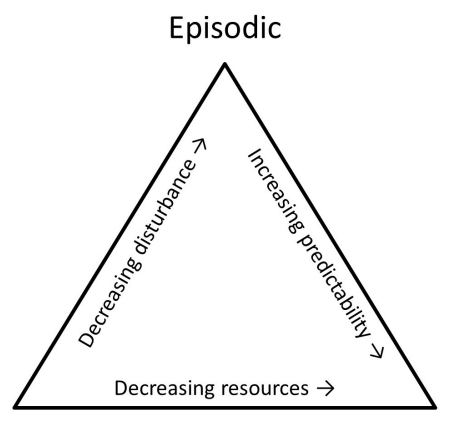

Opportunistic
Equilibrium

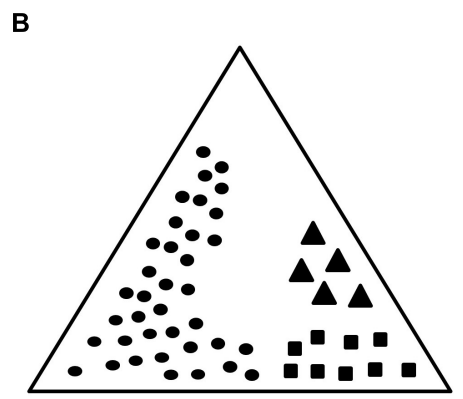

Aquatic larvae
Direct Development
$\triangle$ Paedomorphic

FIGURE 2 | (A) Reproduction of the life-history classification system of Winemiller and Rose (1992). A species' position within the triangle is determined by features of the environment; selection pressures include resource abundance, disturbance regimes, and environmental predictability. (B) Assumed position of life-history strategies for amphibians with aquatic larvae (circles), direct development/viviparity (squares), and paedomorphosis (triangles), based on species age at maturity, fecundity, and juvenile survivorship. Trait data from paedomorphic and direct developing species are scant, so we have presented the hypothetical schematic here. 


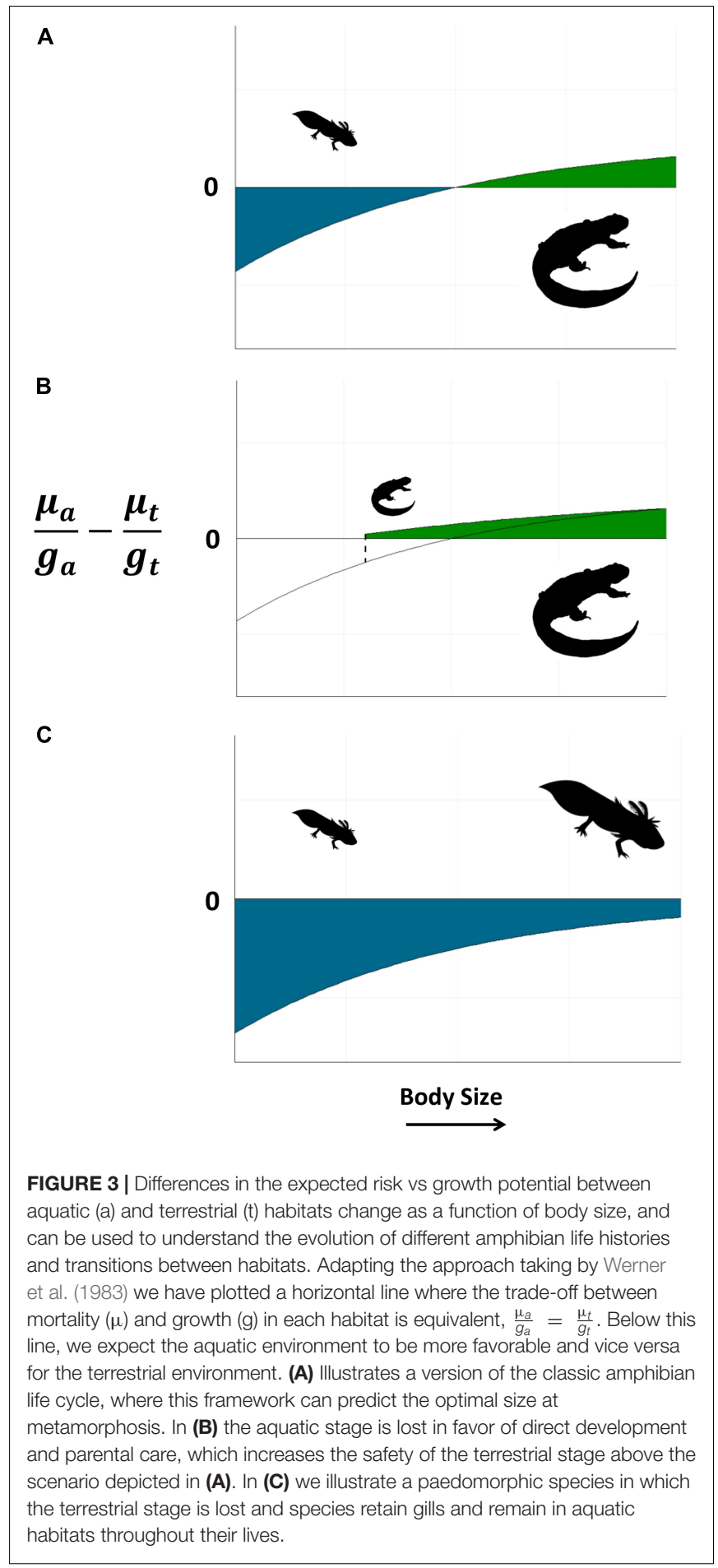

(Martin and Carter, 2013). Direct development is therefore associated with small clutches of large eggs (Salthe, 1969; Salthe and Duellman, 1973; Summers et al., 2007; Silva et al., 2020) and far more prevalent in the humid tropics (Duellman, 1989, 1999; Haddad and Prado, 2005; Martin and Carter, 2013; Lion et al., 2019). The environments that many direct developing species inhabit are relatively stable and resource poor, selecting for equilibrium strategists (Figure 2).

There is also a strong correlation between direct development, duration of the egg stage, and parental care (Petranka, 1998; Kolm and Ahnesjö, 2005; Summers et al., 2006, 2007; Martin and Carter, 2013; Vági et al., 2019, 2020). Direct development enables the evolution of parental care by bringing parent and offspring into the same environment, and is expected to be advantageous given the ability of adults to keep eggs hydrated (Duellman, 1989; Bickford, 2004; Delia et al., 2013; Martin and Carter, 2013; Poo and Bickford, 2013; Schulte et al., 2020; Vági et al., 2020). Further, nest attendance can protect terrestrial eggs from wouldbe predators (Tornik, 2010; McKeon and Summers, 2013; Poo and Bickford, 2013) or fungal infections (Green, 1999; Schulte et al., 2020; Vági et al., 2020).

Frogs and salamanders that exhibit terrestrial egg deposition yet retain the aquatic larval stage show similarities to species with direct development, with comparable reductions in clutch size and a proclivity for parental care (Salthe and Duellman, 1973; Martin and Carter, 2013; Chuang et al., 2017; Schulte et al., 2020). This observation conforms to theoretical expectations given that the risk-reward trade-off for eggs and larvae in aquatic habitats is markedly different. Safety is the only concern for eggs, hence terrestrial egg deposition is typically favored (if eggs can be kept hydrated), but upon hatching, growth potential must be taken into consideration, leading to the retention of aquatic larvae in several clades. Alternatively, larvae may be more effective at ameliorating predation risk compared with eggs; anti-predator behavior in amphibian larvae is well documented (Wells, 2007).

Viviparity lies at the extreme of parental investment, and is similar to direct development in that it eliminates the aquatic life stage and severs an amphibian's ties with the water. Among amphibian orders, viviparity is most common in caecilians; limblessness and a fossorial lifestyle both ameliorate the high costs of egg retention and post-parturition care (Brodie, 1989; Kupfer et al., 2016). As with direct development, viviparity also appears to be related to the availability and profitability of freshwater habitats. Salamandra salamandra has a widespread distribution covering western and central Europe with considerable reproductive diversity (including egg-laying and viviparity) across its range, but live-birth is only exhibited in populations on islands that lack surface water for larval development (García-París et al., 2003). The aridity of the region appears to preclude direct development of eggs (Velo-Antón et al., 2007).

The paucity of viviparity in anuran clades can be explained by the fact that most frogs and toads have external fertilization, precluding a choice between live birth and egg deposition (Townsend et al., 1981; Beck, 1998; Schulte et al., 2020; but see Kühnel et al. (2010)). Of the handful of species that do exhibit internal fertilization, however, many give birth to fully developed froglets/toadlets (Wake, 1978, 1980; Beck, 1998), and one recently described species gives birth to live tadpoles (Iskandar et al., 2014). It has been hypothesized that external fertilization is common in most anurans and may facilitate the evolution of paternal care (Gross and Shine, 1981; Beck, 1998; Benun Sutton and Wilson, 2019). The high relative clutch mass 
of frogs and toads may preclude extensive parental care from the mother in most instances, selecting for alternative strategies. Of note, several live-bearing and "pseudo" live-bearing species (e.g., gastric brooding frogs) have already gone extinct (Blaustein et al., 1994; Iskandar et al., 2014).

Paedomorphism, the process of retaining larval features and developing a fully aquatic lifestyle, is restricted to salamanders. Within a species, paedomorphic and metamorphic populations can occur (Semlitsch et al., 1990; Denoël and Joly, 2001). This unique ability to facultatively alter development offers a chance to understand the selection pressures favoring each morph. Paedomorphism may simply reflect a novel form of resource partitioning if intraspecific competition is reduced when both paedomorphic and metamorphic strategies co-occur (Semlitsch, 1987; Denoël and Joly, 2001), but relative predation pressures on land and in the water, water availability, dispersal limitation, aquatic breathing, terrestrial habitat suitability, and anti-predator refuges have all been shown to influence the ratio of paedomorphs to metamorphs in sympatric populations (Semlitsch, 1987; Jackson and Semlitsch, 1993; Denoël and Ficetola, 2014). In other species with facultative paedomorphosis, there is a tendency for paedomorphic populations to occur in arid regions and at high altitudes, suggesting that environmental pressures on land (extreme temperatures or UV exposure) are selecting for the elimination of the terrestrial stage, physiology permitting (Wells, 2007; Trumbo et al., 2013).

For paedomorphism to evolve, breeding activities must occur in permanent waterbodies (Denoël et al., 2005; Winandy et al., 2015). Of the handful of amphibians that exhibit obligate paedomorphism, most are notably large-bodied species that have presumably evolved to exploit the high growth potential of their aquatic habitats in order to outgrow gape-limited aquatic predators. All four obligate paedomorphic salamander lineages (Cryptobranchidae, Sirenidae, Amphiumidae, and Proteidae) exhibit extensive parental care (Petranka, 1998), indicating that the aquatic environments in which they are found can only be inhabited if the survival of early life-stages can be effectively increased. Paedomorphism may also confer a reproductive advantage both through being able to exploit the productive aquatic environment throughout life, and by avoiding the energetically costly process of metamorphosis (Semlitsch, 1985). In tiger salamander populations, paedomorphic individuals have larger clutches than metamorphic individuals (Whiteman, 1994; Sagar et al., 2007).

\section{CONSERVATION STATUS OF AMPHIBIANS WITH DIFFERENT LIFE HISTORIES}

Amphibians continue to show the steepest population declines of any vertebrate clade (González-del-Pliego et al., 2019), and are faced with numerous, often cumulative, threats (Kiesecker et al., 2001; Collins and Storfer, 2003; Stuart et al., 2004; Sodhi et al., 2008; Pabijan et al., 2020). The relative time spent in aquatic and terrestrial life-stages determines the identity and severity of threats posed to amphibian taxa. In addition, the traits that characterize different amphibian life-history strategies are predicted to influence species' susceptibility to anthropogenic threats, such that species with "faster" life histories are more likely to recover from declines (Pimm et al., 1988; Bennett and Owens, 1997; Hutchings et al., 2012; Pincheira-Donoso et al., 2021). Accordingly, threat status on the IUCN Red List has been related to mode of fertilization (internal vs external), clutch size, egg deposition site, and degree of parental care in several taxa (Hero et al., 2005; Bielby et al., 2008; Sodhi et al., 2008; González-del-Pliego et al., 2019; Pincheira-Donoso et al., 2021).

By relating IUCN threat status with reproductive modes obtained from a global amphibian trait database (Oliveira et al., 2017), we find that direct developers are faring poorly when compared with species exhibiting aquatic larval stages in their assessments (Figures 4, 5). Furthermore, many live-bearing species are Data Deficient on the IUCN Red List (Figures 4, 5), but have been predicted to be more threatened than those already assessed (Howard and Bickford, 2014; but see Bielby et al. (2006)). In other words, the life histories that have the "safest harbors" appear to be in the greatest danger.

That a greater proportion of terrestrial amphibian species are currently threatened with extinction may be a counterintuitive conclusion to some, given that many of the major threats to amphibians (e.g., disease, pollution, and habitat loss) disproportionately affect species with aquatic larvae (Table 1). The small number of paedomorphic species prevents a similar comparison; it can be safely assumed, however, that the predominant threats to paedomorphic populations will be more similar in nature to those faced by species with aquatic larvae than those faced by fully terrestrial amphibians. Thus it seems that paedomorphic species do not appear to be faring as poorly as those with viviparity and direct development. To explore these disparities in more detail, we discuss the major threats to amphibians in the context of each life-history strategy and the ecological drivers that contribute to a species' extinction risk.

\section{Habitat Loss}

A large body of previous work established habitat loss and degradation due to land use change as the primary threat to amphibian diversity. Wetlands are being lost three times faster than forests are being cleared (Wood et al., 2003), with lentic waters (lakes) also suffering heavy losses and degradation (Ricciardi and Rasmussen, 1999; Dudgeon et al., 2006; Liermann et al., 2012; Reid et al., 2019). The elimination of permanent wetlands or changes in the drying regime of ephemeral pools, in addition to pollution, invasions, or thermal changes, will disproportionately affect species that spend all or part of their life in water (Lips et al., 2003; Lion et al., 2019). The Least Concern status of many amphibians with aquatic larvae therefore remains puzzling, and may simply reflect particular biases in the way species are evaluated (Bielby et al., 2006; Becker and Loyola, 2008; Loyola et al., 2008; Becker et al., 2010).

Habitat change varies by continent and habitat type, and could affect species with different geographic ranges differently. Species with small geographic ranges have been shown to be more at risk of extinction, both on theoretical grounds and in reality (Hero et al., 2005; Payne and Finnegan, 2007; Cooper et al., 

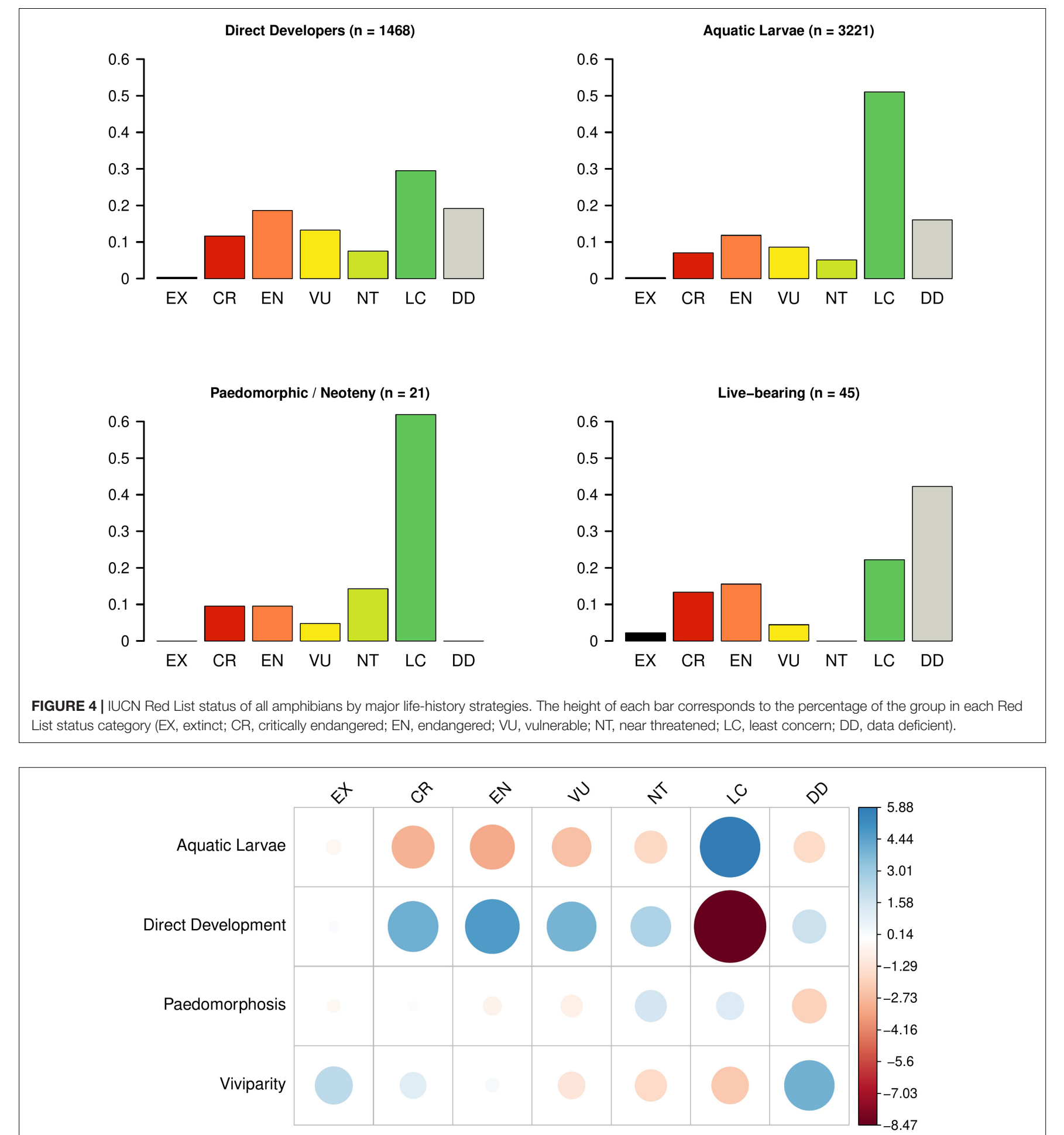

FIGURE 5 | Disparities in conservation status of amphibian life-history strategies $\left(\chi^{2}=242.64, \mathrm{df}=18, p\right.$-value $\left.<2.2 \mathrm{e}-16\right)$. Size and color of points are scaled to Pearson's residuals. Warm colors indicate groups with fewer species expected by chance; cool colors indicate groups with more species than expected.

2008; Sodhi et al., 2008; Smith and Almeida, 2020). Terrestrial species tend to have smaller geographic ranges, perhaps making them more susceptible to habitat loss and stochastic extinction in general (Cooper et al., 2008; Sodhi et al., 2008). Further, many terrestrial amphibians are restricted to tropical regions and mountain ranges, where current threats to intact habitat are most 


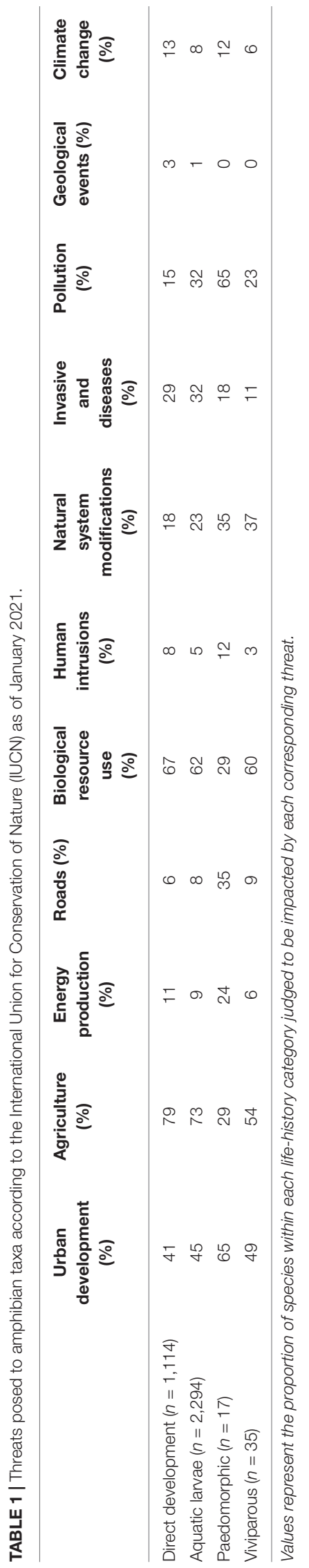

serious (Duellman, 1999; Haddad and Prado, 2005; Lion et al., 2019). Whilst a biogeographical explanation for the observed patterns we see is appealing and intuitive, it fails to explain much of the difference in threat statuses across amphibian clades (Bielby et al., 2006). Thus we must also consider life history as a plausible explanation for these observed differences.

Theory predicts that a species' life history will interact with habitat alterations to determine extinction risk. For example, terrestrial species presumably have evolved parental care, viviparity, or direct development to increase the safety of early life stages. Increased investment per offspring, however, will only be favored if variability in offspring survival is low or can be sufficiently dampened through behavioral means. Thus these strategies are largely restricted to relatively stable environments (Duellman, 1989; Vági et al., 2020). In contrast, the unpredictability of many pond and wetland habitats typically favors high dispersal capabilities, shorter life spans, and larger clutches of small eggs (Green, 2003; Wells, 2007; Semlitsch, 2008; Bonte and Dahirel, 2017). These traits are all associated with an opportunistic breeding strategy that equips populations with a life history that is naturally adapted to persist under anthropogenic stress (Duellman, 1989; Green, 2003; Kindsvater et al., 2016; Allen et al., 2017).

\section{Disease and Invasive Species}

Susceptibility to the introduction of non-native species and/or novel pathogens will be strongly dependent on life history. When considered globally, the most devastating amphibian diseases are water-borne (e.g., chytrid fungus and ranavirus), and could disproportionately imperil species with aquatic larvae (Lips et al., 2003; Piotrowski et al., 2004; Bielby et al., 2008; Smith et al., 2009; Scheele et al., 2014). Fungal pathogens, however, appear to impose challenges to the eggs of both aquatic and terrestrial species (Green, 1999; Pounds et al., 2006; Schulte et al., 2020). Although exposure risk to water-borne diseases such as chytridomycosis and Batrachochytrium salamandrivorans is reduced, terrestrial species may have lower resistance to these pathogens (Mesquita et al., 2017). Indeed, the large eggs of direct developing species are more susceptible due to the longer duration of the egg stage, and the care of eggs (such as brooding) seen in many terrestrial amphibians is thought to be related in part to preventing fungal infection (Green, 1999). Skin secretions from attending parents have been shown to confer pathogen resistance to clutches (Schulte et al., 2020 and references therein), and the high incidence of parental care in all three amphibian orders suggests disease may often play a crucial role. More investigation is needed as to the link between amphibian life histories and susceptibility to disease.

Although less well studied, invasive species will drastically alter the relative safety of aquatic and terrestrial habitats in similar fashion to novel pathogens (Winandy et al., 2015). When sympatric populations of paedomorphic and metamorphic newts are confronted with an introduced predator (stocked fish), the fully aquatic, paedomorphic populations are much more likely to be driven to extinction (Denoël et al., 2005; Pope, 2008). Species with facultative paedomorphosis may be able to persist with merely an alteration in the numbers of paedomorphic and 
metamorphic individuals, but for most taxa invasions will pose a more serious threat (Winandy et al., 2015). If the pressures brought by invasive predators and/or competitors render the aquatic environment completely uninhabitable, fully terrestrial strategies are unlikely to evolve in time (ten Brink et al., 2019, 2020).

\section{Climate Change}

Predicting the impact of climate change will be most difficult for species with multiple life stages that respond differently to rapid shifts in environmental conditions (Kingsolver et al., 2011; Levy et al., 2016). Amphibians' vulnerability will be mediated by the relative time spent in aquatic and terrestrial habitats, and the susceptibility of each stage to alterations in temperature and precipitation regimes. A simple prediction is that aquatic species or life stages will be buffered from environmental perturbations owing to the thermal inertia of water (Martin and Carter, 2013). The environmental conditions at some amphibian breeding wetlands, however, are predicted to become unsuitable with changing precipitation regimes (e.g., Chandler et al., 2016; Lertzman-Lepofsky et al., 2020). Particularly for species that breed in ephemeral wetlands, climate change may shorten hydroperiods, preventing larvae from completing development, or increase the frequency of fish predators being washed in following major storm events. Phenological mismatches are another concern for pond-breeding amphibians. Unless species can adjust the timing of seasonal migrations to fit new rainfall patterns, or relocate to neighboring wetlands with more appropriate hydrological characteristics, successful breeding bouts will become increasingly rare.

Range shifts in response to climatic warming are predicted for many taxa, yet it remains unclear as to what degree amphibians will be able to keep pace with rapid environmental change and relocate to higher altitudes or latitudes (Forero-Medina et al., 2011; Li et al., 2013; Trumbo et al., 2013; Lion et al., 2019). Although we must always consider the possibility that our understanding of dispersal is biased by the difficulty in documenting inter-patch movements (Smith and Green, 2005; Denoël et al., 2018), amphibians as a group appear to have limited mobility (Semlitsch and Bodie, 2003; Pabijan et al., 2020). Low dispersal ability relative to other vertebrates, coupled with strong site fidelity, will certainly heighten amphibians' susceptibility to climate change (Travis et al., 2013). Although no data for caecilians exists, differences in dispersal capabilities and site fidelity appear pronounced between frogs and salamanders (Semlitsch and Bodie, 2003; Smith and Green, 2005). A more solid theoretical framework of amphibian dispersal syndromes is needed to assess the relative vulnerability of the three orders (Buoro and Carlson, 2014; Bonte and Dahirel, 2017).

In the context of developmental modes, dispersal in amphibians occurs almost exclusively in the terrestrial phase (Wilbur and Collins, 1973; Wilbur, 1980; but see Pašukonis et al. (2019)). Paedomorphic species in lentic waters have no dispersal capabilities, and are thus at the mercy of a changing climate. The situation is equally problematic for mountain-top and island endemics, a high proportion of which exhibit direct development (Bielby et al., 2008; Forero-Medina et al., 2011; Lion et al., 2019; Lourenço-de-Moraes et al., 2019, 2020). Further, if direct development is intrinsically linked to small geographic ranges, even species not confined to montane environments may lack the mobility to track viable climatic envelopes (Lion et al., 2019; Lourenço-deMoraes et al., 2019, 2020). Our understanding of amphibian movement is limited and as such the link between lifehistory strategy and dispersal remains unclear, yet such matters carry strong implications for a species susceptibility to anthropogenic threats (Lourenço-de-Moraes et al., 2019, 2020; Pabijan et al., 2020).

\section{Last Resort Interventions}

For some amphibians, the threat of extinction is so serious that captive breeding populations have already been established to minimize the chance to stochastic extinction in the wild. Species with elaborate parental care or complex life cycles are likely to present the greatest challenge with regard to husbandry and captive rearing efforts (Tapley et al., 2015). Further, the commercial importance of species, whether farmed for food or popular in the pet trade, will also have a strong bearing on the speed at which a successful captive facility can be set up. Initiating new breeding programs will be particularly onerous for late-maturing species with small clutch sizes (Elinson et al., 1990; Mohanty and Measey, 2019), and this describes many of the fully terrestrial clades with direct development or viviparity. Several paedomorphic lineages also take multiple years to reach sexual maturity, but their larger clutches and popularity as food or pets may alleviate the difficulties in building captive colonies.

The success of reintroduction efforts is directly correlated with the number of animals released to establish new populations (Germano and Bishop, 2009). Generating the quantity of animals required for reintroductions to represent a viable strategy will take much longer for terrestrial species (Tapley et al., 2015; Harding et al., 2016). The situation is similar when considering translocations of amphibians to areas that are expected to be more hospitable following climate change (assisted dispersal). Translocations attempts will be considerably more challenging for species with direct development, yet it is likely that these species are most in need of such drastic interventions (Tapley et al., 2015). Lastly, it is important to recognize that captive rearing is only a temporary stop-gap that does not address the factors that caused declines in wild populations (Griffiths and Pavajeau, 2008; Scheele et al., 2014; Harding et al., 2016; Pabijan et al., 2020). The ability to eradicate diseases or the time it takes to restore habitats will need to be balanced with the difficulties associated with keeping animals alive in captivity and generating the numbers necessary to attempt reintroductions (Griffiths and Pavajeau, 2008; Scheele et al., 2014; Pabijan et al., 2020).

\section{CONCLUDING REMARKS}

Global amphibian declines have gained increasing recognition and attention, but understanding species' trajectories in the 
context of their differences in life history is a thorny problem. To address this gap, we have brought to bear classic theory that describes and predicts life-history strategies the safe harbor hypothesis, $\mu / \mathrm{g}$, and C-S-R on the intractable problem of understanding why certain amphibian species are threatened with extinction, and others are, to date, of Least Concern.

In the face of multiple threats, and the fact that knowledge of amphibian species richness is still limited - and most species lack basic life-history data on clutch number, lifespan, or other important demographic traits - conservation efforts for amphibians cannot take a one-size-fits-all strategy. We suggest that our framework of risk-reward trade-offs to explain diversity in amphibian life histories - notably developmental and reproductive modes - can offer insights into the distribution of threat status across the tree of amphibians. The complete elimination or addition of a life-history phase to compensate for rapid anthropogenic alterations to aquatic and terrestrial environments appears unlikely; in most instances species with particular life histories will simply go extinct (ten Brink et al., 2019, 2020).

Amphibians with direct developing and viviparous life histories are (proportionally) at greater risk of extinction. The safe harbor provided by mothers of these species may, unfortunately, generate a life history that is intrinsically more sensitive to anthropogenic stressors. The intrinsic connections between developmental mode, clutch size, species range size, and biogeography often put terrestrial species at greater risk (Lion et al., 2019; Pincheira-Donoso et al., 2021). The inherently unpredictable nature of aquatic environments and instability of complex life cycles (Istock, 1967) produces more of a bet-hedging strategy in classic amphibians that may serve them well in light of anthropogenic change. The situation reminds us of Alfred Crosby's take on the progress of civilization, "Specialization almost always narrows the possibilities for future change: for the sake of present convenience, we loot the future."

We suggest there is a role for basic research, focused on species with facultative transitions between paedomorphic and metamorphic lifestyles, or egg laying and viviparity, to gain a deeper understanding of mortality schedules and ecological drivers of life-history transitions. Our theoretical framework provides a basis from which to predict the impact of multiple threats acting synergistically in the context of each life-history strategy and prioritize data deficient species about which little is known (Blaustein and Kiesecker, 2002; Silva et al., 2018). Clades in which direct development or viviparity are common are of special concern, but we cannot rule out the possibility that species with aquatic larvae are equally imperiled, and their IUCN Red List status simply reflect biases in our status assessments when evaluating species with high fecundities and large geographic

\section{REFERENCES}

Abrams, P. A., and Rowe, L. (1996). The effects of predation on the age and size of maturity of prey. Evolution 50, 1052-1061. doi: 10.1111/j.1558-5646.1996. tb02346.x ranges (Bielby et al., 2006; Harper et al., 2008; Middleton and Green, 2015; Lion et al., 2019).

We acknowledge that life histories alone will not account for all of the factors vulnerability assessments aim to capture (Bielby et al., 2006; Becker and Loyola, 2008; Loyola et al., 2008; Becker et al., 2010). However, by highlighting discrepancies in threat status and vulnerability, our approach may help to reveal species or regions where exposure to anthropogenic threats is particularly acute and where interventions are most needed. Communities in which diverse life histories are present will prove particularly useful in disentangling the contributions of exposure and innate vulnerability in determining a species' extinction risk.

\section{DATA AVAILABILITY STATEMENT}

The datasets presented in this study can be found in online repositories. The names of the repository/repositories and accession number(s) can be found below: life-history data were obtained from AmphiBIO, a global amphibian trait database (Oliveira et al., 2017), and can be accessed at doi: 10.1038/sdata.2017.123. Red List categories were downloaded from the IUCN Red List of threatened species on 21st March 2021, https://www.iucnredlist.org.

\section{AUTHOR CONTRIBUTIONS}

GB and HK were involved in conceptual development, writing, and editing. GB performed the statistical analyses and created the figures. Both authors contributed to the article and approved the submitted version.

\section{FUNDING}

Financial support for this project was provided by the Department of Fish and Wildlife Conservation at Virginia Tech and the Virginia Tech Open Access Subvention Fund.

\section{ACKNOWLEDGMENTS}

We would like to thank J. Barron, N. Caruso, H. Chandler, H. Conrad, C. Haas, T. DuBose, M. Holden, M. Mims, K. Theberge, D. Trumbo, and two reviewers for comments on an earlier draft that greatly improved the manuscript. We would also like to thank M. Haack for assistance in obtaining data from the IUCN Red List. in pool frogs. Ecology 83, 2542-2551. doi: 10.2307/3071813 
Arendt, J. D., and Wilson, D. S. (1999). Countergradient selection for rapid growth in pumpkinseed sunfish: disentangling ecological and evolutionary effects. Ecology 80, 2793-2798. doi: 10.2307/177259

Beck, C. W. (1998). Mode of fertilization and parental care in anurans. Anim. Behav. 55, 439-449. doi: 10.1006/anbe.1997.0619

Becker, C. G., and Loyola, R. D. (2008). Extinction risk assessments at the population and species level: implications for amphibian conservation. Biodivers. Conserv. 17, 2297-2304. doi: 10.1007/s10531-007-9298-8

Becker, C. G., Loyola, R. D., Haddad, C. F. B., and Zamudio, K. R. (2010). Integrating species life-history traits and patterns of deforestation in amphibian conservation planning. Divers. Distrib. 16, 10-19. doi: 10.1111/j.1472-4642. 2009.00625.x

Bennett, P. M., and Owens, I. P. (1997). Variation in extinction risk among birds: chance or evolutionary predisposition? Proc. R. Soc. B 264, 401-408. doi: 10. 1098/rspb.1997.0057

Benun Sutton, F., and Wilson, A. B. (2019). Where are all the moms? External fertilization predicts the rise of male parental care in bony fishes. Evolution 73, 2451-2460. doi: 10.1111/evo.13846

Berrigan, D., and Charnov, E. L. (1994). Reaction norms for age and size at maturity in response to temperature: a puzzle for life historians. OIKOS 70, 474-478. doi: $10.2307 / 3545787$

Bickford, D. P. (2004). Differential parental care behaviors of arboreal and terrestrial microhylid frogs from Papua New Guinea. Behav. Ecol. Sociobiol. 55, 402-409. doi: 10.1007/s00265-003-0717-x

Bielby, J., Cooper, N., Cunningham, A., Garner, T. W. J., and Purvis, A. (2008). Predicting susceptibility to future declines in the world's frogs. Conserv. Lett. 1, 82-90. doi: 10.1111/j.1755-263X.2008.00015.x

Bielby, J., Cunningham, A. A., and Purvis, A. (2006). Taxonomic selectivity in amphibians: ignorance, geography or biology? Anim. Conserv. 9, 135-143. doi: $10.1111 / j .1469-1795.2005 .00013 . x$

Blaustein, A. R., and Kiesecker, J. M. (2002). Complexity in conservation: lessons from the global decline of amphibian populations. Ecol. Lett. 5, 597-608. doi: 10.1046/j.1461-0248.2002.00352.x

Blaustein, A. R., Wake, D. B., and Sousa, W. P. (1994). Amphibian declines: judging stability, persistence, and susceptibility of populations to local and global extinctions. Conserv. Biol. 8, 60-71. doi: 10.1046/j.1523-1739.1994.08010060.x

Bonte, D., and Dahirel, M. (2017). Dispersal: a central and independent trait in life history. OIKOS 126, 472-479. doi: 10.1111/oik.03801

Brodie, E. D. III (1989). Behavioral modification as a means of reducing the cost of reproduction. Am. Nat. 134, 225-238. doi: 10.1086/284977

Buoro, M., and Carlson, S. M. (2014). Life-history syndromes: integrating dispersal through space and time. Ecol. Lett. 17, 756-767. doi: 10.1111/ele.12275

Chandler, H. C., Rypel, A. L., Jiao, Y., Haas, C. A., and Gorman, T. A. (2016). Hindcasting historical breeding conditions for an endangered salamander in ephemeral wetlands of the southeastern USA: implications of climate change. PLoS One 11, e0150169. doi: 10.1371/journal.pone.0150169

Chuang, M. F., Lee, W. H., Sun, J. S., You, C. H., Kam, Y. C., and Poo, S. (2017). Predation risk and breeding site value determine male behavior and indirectly affect survivorship of their offspring. Behav. Ecol. Sociobiol. 71, 1-7. doi: 10.1007/s00265-017-2349-6

Collins, J. P., and Storfer, A. (2003). Global amphibian declines: sorting the hypotheses. Divers. Distrib. 9, 89-98. doi: 10.1046/j.1472-4642.2003.00012.x

Cooper, N., Bielby, J., Thomas, G. H., and Purvis, A. (2008). Macroecology and extinction risk correlates of frogs. Glob. Ecol. Biogeogr. 17, 211-221. doi: 10. $1111 / j .1466-8238.2007 .00355 . x$

Davenport, J. M., and Summers, K. (2010). Environmental influences on egg and clutch sizes in lentic-and lotic-breeding salamanders. J. Herpetol. 9, 87-98.

Delia, J. R. J., Ramirez-Bautista, A., and Summers, K. (2013). Parents adjust care in response to weather conditions and egg dehydration in a Neotropical glassfrog. Behav. Ecol. Sociobiol. 67, 557-569. doi: 10.1007/s00265-013$1475-z$

Denoël, M., and Ficetola, G. F. (2014). Heterochrony in a complex world: disentangling environmental processes of facultative paedomorphosis in an amphibian. J. Anim. Ecol. 83, 606-615. doi: 10.1111/1365-2656.12173

Denoël, M., and Joly, P. (2001). Adaptive significance of facultative paedomorphosis in Triturus alpestris (Amphibia, Caudata): resource partitioning in an alpine lake. Freshw. Biol. 46, 1387-1396. doi: $10.1046 / j .1365-2427.2001 .00762 . x$
Denoël, M., Dalleur, S., Langrand, E., Besnard, A., and Cayuela, H. (2018). Dispersal and alternative breeding site fidelity strategies in an amphibian. Ecography 41, 1543-1555. doi: 10.1111/ecog.03296

Denoël, M., Dzukic, G., and Kalezic, M. (2005). Effect of widespread fish introductions on paedomorphic newts in Europe. Conserv. Biol. 19, 162-170. doi: 10.1111/j.1523-1739.2005.00001.x

Dmitriew, C. M. (2011). The evolution of growth trajectories: what limits growth rate? Biol. Rev. 86, 97-116. doi: 10.1111/j.1469-185X.2010.00136.x

Dudgeon, D., Arthington, A. H., Gessner, M. O., Kawabata, Z. I., Knowler, D. J., Lévêque, C., et al. (2006). Freshwater biodiversity: importance, threats, status and conservation challenges. Biol. Rev. 81, 163-182. doi: 10.1017/ S1464793105006950

Duellman, W. E. (1989). "Alternative life-history styles in anuran amphibians: evolutionary and ecological implications," in Alternative Life-history Styles of Animals, ed. M. N. Bruton (Dordrecht: Springer), 1010-1126.

Duellman, W. E. (1999). Patterns of Distribution of Amphibians: A Global Perspective. Baltimore, MD: Johns Hopkins University Press.

Duellman, W. E., and Trueb, L. (1994). Biology of Amphibians. Baltimore, MD: Johns Hopkins University Press.

Elinson, R. P., Del Pino, E. M., Townsend, D. S., Cuesta, F. C., and Eichhorn, P. (1990). A practical guide to the developmental biology of terrestrial-breeding frogs. Biol. Bull. 179, 163-177. doi: 10.2307/1541765

Fiksen, $\varnothing$, and Jørgensen, C. (2011). Model of optimal behaviour in fish larvae predicts that food availability determines survival, but not growth. Mar. Ecol. Prog. Ser. 432, 207-219. doi: 10.3354/meps09148

Foden, W. B., Butchart, S. H., Stuart, S. N., Vié, J. C., Akçakaya, H. R., Angulo, A., et al. (2013). Identifying the world's most climate change vulnerable species: a systematic trait-based assessment of all birds, amphibians and corals. PLoS One 8:e65427. doi: 10.1371/journal.pone.0065427

Forero-Medina, G., Joppa, L., and Pimm, S. L. (2011). Constraints to species' elevational range shifts as climate changes. Conserv. Biol. 25, 163-171. doi: 10.1111/j.1523-1739.2010.01572.x

García-París, M., Alcobendas, M., Buckley, D., and Wake, D. B. (2003). Dispersal of viviparity across contact zones in Iberian populations of fire salamanders (Salamandra) inferred from discordance of genetic and morphological traits. Evolution 57, 129-143. doi: 10.1111/j.0014-3820.2003.tb00221.x

Germano, J. M., and Bishop, P. J. (2009). Suitability of amphibians and reptiles for translocation. Conserv. Biol. 23, 7-15. doi: 10.1111/j.1523-1739.2008.01123.x

González-del-Pliego, P., Freckleton, R. P., Edwards, D. P., Koo, M. S., Scheffers, B. R., Pyron, R. A., et al. (2019). Phylogenetic and trait-based prediction of extinction risk for data-deficient amphibians. Curr. Biol. 29, 1557-1563. doi: 10.1016/j.cub.2019.04.005

Green, A. (1999). Implications of pathogenic fungi for life-history evolution in amphibians. Funct. Ecol. 13, 573-575. doi: 10.1046/j.1365-2435.1999.00336.x

Green, D. M. (2003). The ecology of extinction: population fluctuation and decline in amphibians. Biol. Conserv. 111, 331-343. doi: 10.1016/S0006-3207(02) 00302-6

Griffiths, R. A., and Pavajeau, L. (2008). Captive breeding, reintroduction, and the conservation of amphibians. Conserv. Biol. 22, 852-861. doi: 10.1111/j.15231739.2008.00967.x

Grime, J. P. (1977). Evidence for the existence of three primary strategies in plants and its relevance to ecological and evolutionary theory. Am. Nat. 111, 1169-1194. doi: 10.1086/283244

Gross, M. R., and Shine, R. (1981). Parental care and mode of fertilization in ectothermic vertebrates. Evolution 35, 775-793. doi: 10.2307/2408247

Haddad, C. F., and Prado, C. P. (2005). Reproductive modes in frogs and their unexpected diversity in the Atlantic Forest of Brazil. BioScience 55, 207-217. doi: 10.1641/0006-3568(2005)055[0207:rmifat]2.0.co;2

Harding, G., Griffiths, R. A., and Pavajeau, L. (2016). Developments in amphibian captive breeding and reintroduction programs. Conserv. Biol. 30, 340-349. doi: $10.1111 /$ cobi. 12612

Harper, E. B., Rittenhouse, T. A., and Semlitsch, R. D. (2008). Demographic consequences of terrestrial habitat loss for pool-breeding amphibians: predicting extinction risks associated with inadequate size of buffer zones. Conserv. Biol. 22, 1205-1215. doi: 10.1111/j.1523-1739.2008.01015.x

He, F., Langhans, S. D., Zarfl, C., Wanke, R., Tockner, K., and Jähnig, S. C. (2021). Combined effects of life-history traits and human impact on extinction risk of freshwater megafauna. Conserv. Biol. 35, 643-653. doi: 10.1111/cobi.13590 
Hero, J. M., Williams, S. E., and Magnusson, W. E. (2005). Ecological traits of declining amphibians in upland areas of eastern Australia. J. Zool. 267, 221-232. doi: 10.1017/S0952836905007296

Hoffmann, M., Hilton-Taylor, C., Angulo, A., Böhm, M., Brooks, T. M., Butchart, S. H., et al. (2010). The impact of conservation on the status of the world's vertebrates. Science 330, 1503-1509. doi: 10.1126/science.1194442

Howard, S. D., and Bickford, D. P. (2014). Amphibians over the edge: silent extinction risk of Data Deficient species. Divers. Distrib. 20, 837-846. doi: 10.1111/ddi.12218

Hutchings, J. A. (1993). Adaptive life histories effected by age-specific survival and growth rate. Ecology 74, 673-684. doi: 10.2307/1940795

Hutchings, J. A., Myers, R. A., García, V. B., Lucifora, L. O., and Kuparinen, A. (2012). Life-history correlates of extinction risk and recovery potential. Ecol. Appl. 22, 1061-1067. doi: 10.1890/11-1313.1

Iskandar, D. T., Evans, B. J., and McGuire, J. A. (2014). A novel reproductive mode in frogs: a new species of fanged frog with internal fertilization and birth of tadpoles. PLoS One 9:e115884. doi: 10.1371/journal.pone.0115884

Istock, C. A. (1967). The evolution of complex life cycle phenomena: an ecological perspective. Evolution 21, 592-605. doi: 10.2307/2406619

IUCN (2021). The IUCN Red List of Threatened Species. Version 2021-3. Available online at: https://www.iucnredlist.org (accessed January 22, 2022).

Jackson, M. E., and Semlitsch, R. D. (1993). Paedomorphosis in the salamander Ambystoma talpoideum: effects of a fish predator. Ecology 74, 342-350. doi: $10.2307 / 1939297$

Jørgensen, C., Auer, S. K., and Reznick, D. N. (2011). A model for optimal offspring size in fish, including live-bearing and parental effects. Am. Nat. 177, E119-E135. doi: 10.1086/659622

Kiesecker, J. M., Blaustein, A. R., and Belden, L. K. (2001). Complex causes of amphibian population declines. Nature 410, 681-684. doi: 10.1038/35070552

Kindsvater, H. K., Mangel, M., Reynolds, J. D., and Dulvy, N. K. (2016). Ten principles from evolutionary ecology essential for effective marine conservation. Ecol. Evol. 6, 2125-2138. doi: 10.1002/ece3.2012

Kingsolver, J. G., Arthur Woods, H., Buckley, L. B., Potter, K. A., MacLean, H. J., and Higgins, J. K. (2011). Complex life cycles and the responses of insects to climate change. Integr. Comp. Biol. 51, 719-732. doi: 10.1093/icb/icr015

Kolm, N., and Ahnesjö, I. (2005). Do egg size and parental care coevolve in fishes? J. Fish Biol. 66, 1499-1515. doi: 10.1111/j.0022-1112.2005.00777.x

Kühnel, S., Reinhard, S., and Kupfer, A. (2010). Evolutionary reproductive morphology of amphibians: an overview. Bonn Zool. Bull. 57, 119-126.

Kupfer, A., Maxwell, E., Reinhard, S., and Kuehnel, S. (2016). The evolution of parental investment in caecilian amphibians: a comparative approach. Biol. J. Linn. Soc. 119, 4-14. doi: 10.1111/bij.12805

Lertzman-Lepofsky, G. F., Kissel, A. M., Sinervo, B., and Palen, W. J. (2020). Water loss and temperature interact to compound amphibian vulnerability to climate change. Glob. Change Biol. 26, 4868-4879. doi: 10.1111/gcb.15231

Levy, O., Buckley, L. B., Keitt, T. H., and Angilletta, M. J. Jr. (2016). Ontogeny constrains phenology: opportunities for activity and reproduction interact to dictate potential phenologies in a changing climate. Ecol. Lett. 19, 620-628. doi: 10.1111/ele.12595

Li, Y., Cohen, J. M., and Rohr, J. R. (2013). Review and synthesis of the effects of climate change on amphibians. Integr. Zool. 8, 145-161. doi: 10.1111/17494877.12001

Liermann, C. R., Nilsson, C., Robertson, J., and Ng, R. Y. (2012). Implications of dam obstruction for global freshwater fish diversity. BioScience 62, 539-548. doi: 10.1525/bio.2012.62.6.5

Lima, S. L., and Dill, L. M. (1990). Behavioural decisions made under the risk of predation - A review and prospectus. Can. J. Zool. 68, 619-640. doi: 10.1139/ z90-092

Lion, M. B., Mazzochini, G. G., Garda, A. A., Lee, T. M., Bickford, D., Costa, G. C., et al. (2019). Global patterns of terrestriality in amphibian reproduction. Glob. Ecol. Biogeogr. 28, 744-756. doi: 10.1111/geb.12886

Lips, K. R., Reeve, J. D., and Witters, L. R. (2003). Ecological traits predicting amphibian population declines in Central America. Conserv. Biol. 17, 10781088. doi: 10.1046/j.1523-1739.2003.01623.x

Lourenço-de-Moraes, R., Campos, F. S., Ferreira, R. B., Beard, K. H., Solé, M., Llorente, G. A., et al. (2020). Functional traits explain amphibian distribution in the Brazilian Atlantic Forest. J. Biogeogr. 47, 275-287. doi: 10.1111/jbi. 13727
Lourenço-de-Moraes, R., Campos, F. S., Ferreira, R. B., Solé, M., Beard, K. H., and Bastos, R. P. (2019). Back to the future: conserving functional and phylogenetic diversity in amphibian-climate refuges. Biodivers. Conserv. 28, 1049-1073. doi: 10.1007/s10531-019-01706-x

Loyola, R. D., Becker, C. G., Kubota, U., Haddad, C. F. B., Fonseca, C. R., and Lewinsohn, T. M. (2008). Hung out to dry: choice of priority ecoregions for conserving threatened Neotropical anurans depends on life-history traits. PLoS One 3:e2120. doi: 10.1371/journal.pone.0002120

Ludwig, D., and Rowe, L. (1990). Life-history strategies for energy gain and predator avoidance under time constraints. Am. Nat. 135, 686-707. doi: 10. $1086 / 285069$

Ma, L., Buckley, L. B., Huey, R. B., and Du, W. G. (2018). A global test of the coldclimate hypothesis for the evolution of viviparity of squamate reptiles. Glob. Ecol. Biogeogr. 27, 679-689. doi: 10.1111/geb.12730

Martin, K. L., and Carter, A. L. (2013). Brave new propagules: terrestrial embryos in anamniotic eggs. Integr. Comp. Biol. 53, 233-247. doi: 10.1093/icb/ict018

McKeon, C. S., and Summers, K. (2013). Predator driven reproductive behavior in a tropical frog. Evol. Ecol. 27, 725-737. doi: 10.1007/s10682-0139641-3

Mesquita, A. F. C., Lambertini, C., Lyra, M., Malagoli, L. R., James, T. Y., Toledo, L. F., et al. (2017). Low resistance to chytridiomycosis in direct-developing amphibians. Sci. Rep. 7:16605. doi: 10.1038/s41598-017-16425-y

Middleton, J., and Green, D. M. (2015). Adult age-structure variability in an amphibian in relation to population decline. Herpetologica 71, 190-195. doi: 10.1655/HERPETOLOGICA-D-14-00074

Mitchell, N. J. (2002). Nest-site selection in a terrestrial-breeding frog with protracted development. Aust. J. Zool. 50, 225-235. doi: 10.1071/ZO0 1086

Mohanty, N. P., and Measey, J. (2019). The global pet trade in amphibians: species traits, taxonomic bias, and future directions. Biodivers. Conserv. 28, 3915-3923. doi: 10.1007/s10531-019-01857-x

Nussbaum, R. A. (1987). Parental care and egg size in salamanders: an examination of the safe harbor hypothesis. Res. Pop. Ecol. 29, 27-44. doi: 10.1007/ BF02515423

Nussbaum, R. A., and Schultz, D. L. (1989). Coevolution of parental care and egg size. Am. Nat. 133, 591-603. doi: 10.1086/284939

Oliveira, B. F., São-Pedro, V. A., Santos-Barrera, G., Penone, C., and Costa, G. C. (2017). AmphiBIO, a global database for amphibian ecological traits. Sci. Data 4:170123. doi: 10.1038/sdata.2017.123

Pabijan, M., Palomar, G., Antunes, B., Antoł, W., Zieliñski, P., and Babik, W. (2020). Evolutionary principles guiding amphibian conservation. Evol. Appl. 13, 857-878. doi: 10.1111/eva.12940

Pašukonis, A., Loretto, M. C., and Rojas, B. (2019). How far do tadpoles travel in the rainforest? Parent-assisted dispersal in poison frogs. Evol. Ecol. 33, 613-623. doi: 10.1007/s10682-019-09994-z

Payne, J. L., and Finnegan, S. (2007). The effect of geographic range on extinction risks during background and mass extinction. Proc. Natl. Acad. Sci. U.S.A. 104, 10506-10511. doi: 10.1073/pnas.0701257104

Pepin, P., Dower, J. F., and Davidson, F. J. M. (2003). A spatially explicit study of prey-predator interactions in larval fish: assessing the influence of food and predator abundance on larval growth and survival. Fish. Oceanogr. 12, 19-33. doi: 10.1046/j.1365-2419.2003.00221.x

Perrin, N. (1995). About Berrigan and Charnov's life-history puzzle. OIKOS 73, 137-139. doi: 10.2307/3545737

Petranka, J. W. (1990). Observations on nest site selection, nest desertion, and embryonic survival in marbled salamanders. J. Herpetol. 24, 229-234. doi: 10. 2307/1564387

Petranka, J. W. (1998). Salamanders of the United States and Canada. Washington DC: Smithsonian Institution Press.

Petranka, J. W., and Petranka, J. G. (1981). On the evolution of nest site selection in the marbled salamander, Ambystoma opacum. Copeia 1981, 387-391. doi: $10.2307 / 1444227$

Pimm, S. L., Jones, H. L., and Diamond, J. (1988). On the risk of extinction. Am. Nat. 132, 757-785. doi: 10.1086/284889

Pincheira-Donoso, D., Harvey, L. P., Cotter, S. C., Stark, G., Meiri, S., and Hodgson, D. J. (2021). The global macroecology of brood size in amphibians reveals a predisposition of low-fecundity species to extinction. Glob. Ecol. Biogeogr. 30, 1299-1310. doi: 10.1111/geb.13287 
Piotrowski, J. S., Annis, S. L., and Longcore, J. E. (2004). Physiology of Batrachochytrium dendrobatidis, a chytrid pathogen of amphibians. Mycologia 96, 9-15. doi: 10.2307/3761981

Poo, S., and Bickford, D. P. (2013). The adaptive significance of egg attendance in a south-east Asian tree frog. Ethology 119, 671-679. doi: 10.1111/eth.12108

Pope, K. L. (2008). Assessing changes in amphibian population dynamics following experimental manipulations of introduced fish. Conserv. Biol. 22, 1572-1581. doi: 10.1111/j.1523-1739.2008.00998.x

Pounds, J. A., Bustamante, M. R., Coloma, L. A., Consuegra, J. A., Michael, P. L., Fogden, M. P. L., et al. (2006). Widespread amphibian extinctions from epidemic disease driven by global warming. Nature 439, 161-167. doi: 10.1038/ nature 04246

Reid, A. J., Carlson, A. K., Creed, I. F., Eliason, E. J., Gell, P. A., Johnson, P. T., et al. (2019). Emerging threats and persistent conservation challenges for freshwater biodiversity. Biol. Rev. 94, 849-873. doi: 10.1111/brv.12480

Relyea, R. A. (2001). Morphological and behavioral plasticity of larval anurans in response to different predators. Ecology 82, 523-540. doi: 10.2307/2679877

Ricciardi, A., and Rasmussen, J. B. (1999). Extinction rates of North American freshwater fauna. Conserv. Biol. 13, 1220-1222. doi: 10.1046/j.1523-1739.1999. 98380.x

Roff, D. A. (2002). Life History Evolution. Sunderland, MA: Sinauer Associates.

Rowe, L., and Ludwig, D. (1991). Size and timing of metamorphosis in complex life cycles: time constraints and variation. Ecology 72, 413-427. doi: 10.2307/ 2937184

Rudolf, V. H. W., and Rödel, M. O. (2007). Phenotypic plasticity and optimal timing of metamorphosis under uncertain time constraints. Evol. Ecol. 21, 121-142. doi: 10.1007/s10682-006-0017-9

Sagar, J. P., Olson, D. H., and Schmitz, R. A. (2007). Survival and growth of larval coastal giant salamanders (Dicamptodon tenebrosus) in streams in the Oregon Coast Range. Copeia 2007, 123-130. doi: 10.1643/0045-8511(2007) 7[123:sagolc $] 2.0 . c 0 ; 2$

Salthe, S. N. (1969). Reproductive modes and the number and sizes of ova in the urodeles. Am. Midl. Nat. 81, 467-490. doi: 10.2307/2423983

Salthe, S. N., and Duellman, W. E. (1973). "Quantitative constraints associated with reproductive mode in anurans," in Evolutionary Biology of the Anurans: Contemporary Research on Major Problems, ed. J. L. Vial (Columbia, MO: University of Missouri Press).

Sargent, R. C., Taylor, P. D., and Gross, M. R. (1987). Parental care and the evolution of egg size in fishes. Am. Nat. 129, 32-46. doi: 10.1086/28 4621

Scheele, B. C., Hunter, D. A., Grogan, L. F., Berger, L. E. E., Kolby, J. E., McFadden, M. S., et al. (2014). Interventions for reducing extinction risk in chytridiomycosis-threatened amphibians. Conserv. Biol. 28, 1195-1205. doi: 10.1111/cobi.12322

Schulte, L. M., Ringler, E., Rojas, B., and Stynoski, J. L. (2020). Developments in amphibian parental care research: history, present advances, and future perspectives. Herpetol. Monogr. 34, 71-97. doi: 10.1655/HERPMONOGRAPHS-D- 19-00002.1

Semlitsch, R. D. (1985). Reproductive strategy of a facultatively paedomorphic salamander Ambystoma talpoideum. Oecologia 65, 305-313. doi: 10.1007/ BF00378903

Semlitsch, R. D. (1987). Paedomorphosis in Ambystoma talpoideum: effects of density, food, and pond drying. Ecology 68, 994-1002. doi: 10.2307/1938370

Semlitsch, R. D. (2008). Differentiating migration and dispersal processes for pond-breeding amphibians. J. Wildl. Manag. 72, 260-267. doi: 10.2193/2007082

Semlitsch, R. D., and Bodie, J. R. (2003). Biological criteria for buffer zones around wetlands and riparian habitats for amphibians and reptiles. Conserv. Biol. 17, 1219-1228. doi: 10.1046/J.1523-1739.2003.02177.X

Semlitsch, R. D., and Wilbur, H. M. (1988). Effects of pond drying time on metamorphosis and survival in the salamander Ambystoma talpoideum. Copeia 4, 978-983. doi: 10.2307/1445721

Semlitsch, R. D., Harris, R. N., and Wilbur, H. M. (1990). Paedomorphosis in Ambystoma talpoideum: maintenance of population variation and alternative life-history pathways. Evolution 44, 1604-1613. doi: 10.1111/j.1558-5646.1990. tb03849.x

Sevenster, J. G. (1995). Equations or organisms? A comment on Berrigan and Charnov. OIKOS 73, 405-407. doi: 10.2307/3545966
Shine, R. (1978). Propagule size and parental care: the "safe harbor" hypothesis. J. Theor. Biol. 75, 417-424. doi: 10.1016/0022-5193(78)90353-3

Shine, R., and Harlow, P. S. (1996). Maternal manipulation of offspring phenotypes via nest-site selection in an oviparous lizard. Ecology 77, 1808-1817. doi: 10. 2307/2265785

Shine, R., Elphick, M. J., and Barrott, E. G. (2003). Sunny side up: lethally high, not low, nest temperatures may prevent oviparous reptiles from reproducing at high elevations. Biol. J. Linn. Soc. 78, 325-334. doi: 10.1046/j.1095-8312.2003. 00140.x

Sih, A., and Moore, R. D. (1993). Delayed hatching of salamander eggs in response to enhanced larval predation risk. Am. Nat. 142, 947-960. doi: 10.1086/285583

Sih, A., Bell, A. M., Johnson, J. C., and Ziemba, R. E. (2004). Behavioral syndromes: an integrative overview. Q. Rev. Biol. 79, 241-277. doi: 10.1086/422893

Silva, N. R., Berneck, B. V., da Silva, H. R., Haddad, C. F., Zamudio, K. R., Mott, T., et al. (2020). Egg-laying site, fecundity and degree of sexual size dimorphism in frogs. Biol. J. Linn. Soc. 131, 600-610. doi: 10.1093/biolinnean/blaa126

Silva, Y. B. D. S. E., Ribeiro, B. R., Thiesen Brum, F., Soares-Filho, B., Loyola, R., and Michalski, F. (2018). Combined exposure to hydroelectric expansion, climate change and forest loss jeopardies amphibians in the Brazilian Amazon. Divers. Distrib. 24, 1072-1082. doi: 10.1111/ddi.12745

Skelly, D. K., and Werner, E. E. (1990). Behavioral and life-historical responses of larval American toads to an odonate predator. Ecology 71, 2313-2322. doi: $10.2307 / 1938642$

Smith, A. M., and Green, D. M. (2005). Dispersal and the metapopulation paradigm in amphibian ecology and conservation: are all amphibian populations metapopulations? Ecography 28, 110-128. doi: 10.1111/j.0906-7590.2005. 04042.x

Smith, K. G., and Almeida, R. J. (2020). When are extinctions simply bad luck? Rarefaction as a framework for disentangling selective and stochastic extinctions. J. Appl. Ecol. 57, 101-110. doi: 10.1111/1365-2664.13510

Smith, K. G., Lips, K. R., and Chase, J. M. (2009). Selecting for extinction: nonrandom disease-associated extinction homogenizes amphibian biotas. Ecol. Lett. 12, 1069-1078. doi: 10.1111/j.1461-0248.2009.01363.x

Sodhi, N. S., Bickford, D., Diesmos, A. C., Lee, T. M., Koh, L. P., Brook, B. W., et al. (2008). Measuring the meltdown: drivers of global amphibian extinction and decline. PLoS One 3:e1636. doi: 10.1371/journal.pone.0001636

Southwood, T. R. E. (1988). Tactics, strategies and templets. OIKOS 52, 3-18. doi: $10.2307 / 3565974$

Stamps, J. A. (2007). Growth-mortality tradeoffs and 'personality traits' in animals. Ecol. Lett. 10, 355-363. doi: 10.1111/j.1461-0248.2007.01034.x

Stuart, S. N., Chanson, J. S., Cox, N. A., Young, B. E., Rodrigues, A. S., Fischman, D. L., et al. (2004). Status and trends of amphibian declines and extinctions worldwide. Science 306, 1783-1786. doi: 10.1126/science.1103538

Summers, K., McKeon, C. S., Heying, H., Hall, J., and Patrick, W. (2007). Social and environmental influences on egg size evolution in frogs. J. Zool. 271, 225-232. doi: 10.1111/j.1469-7998.2006.00213.x

Summers, K., Sea McKeon, C., and Heying, H. (2006). The evolution of parental care and egg size: a comparative analysis in frogs. Proc. R. Soc. B 273, 687-692. doi: 10.1098/rspb.2005.3368

Tapley, B., Bradfield, K. S., Michaels, C., and Bungard, M. (2015). Amphibians and conservation breeding programmes: do all threatened amphibians belong on the ark? Biodivers. Conserv. 24, 2625-2646. doi: 10.1007/s10531-0150966-9

Taylor, B. E., Scott, D. E., and Gibbons, J. W. (2006). Catastrophic reproductive failure, terrestrial survival, and persistence of the marbled salamander. Conserv. Biol. 20, 792-801. doi: 10.1111/j.1523-1739.2005.00321.x

ten Brink, H., de Roos, A. M., and Dieckmann, U. (2019). The evolutionary ecology of metamorphosis. Am. Nat. 193, E116-E131. doi: 10.1086/70 1779

ten Brink, H., Onstein, R. E., and de Roos, A. M. (2020). Habitat deterioration promotes the evolution of direct development in metamorphosing species. Evolution 74, 1826-1850. doi: 10.1111/evo.14040

Tornik, J. K. (2010). Factors affecting aggression during nest guarding in the eastern red-backed salamander (Plethodon cinereus). Herpetologica 66, 385-392. doi: 10.1655/09-037a.1

Townsend, D. S., Stewart, M. M., Pough, F. H., and Brussard, P. F. (1981). Internal fertilization in an oviparous frog. Science 212, 469-471. doi: 10.1126/science. 6894203 
Travis, J. M., Delgado, M., Bocedi, G., Baguette, M., Bartoñ, K., Bonte, D., et al. (2013). Dispersal and species' responses to climate change. OIKOS 122, 15321540. doi: 10.1111/j.1600-0706.2013.00399.x

Trumbo, D. R., Spear, S. F., Baumsteiger, J., and Storfer, A. (2013). Rangewide landscape genetics of an endemic Pacific northwestern salamander. Mol. Ecol. 22, 1250-1266. doi: $10.1111 /$ mec. 12168

Urban, M. C. (2007). The growth-predation risk trade-off under a growing gapelimited predation threat. Ecology 88, 2587-2597. doi: 10.1890/06-1946.1

Urban, M. C. (2008). Salamander evolution across a latitudinal cline in gapelimited predation risk. OIKOS 117, 1037-1049. doi: 10.1111/J.0030-1299.2008. 16334.X

Vági, B., Végvári, Z., Liker, A., Freckleton, R. P., and Székely, T. (2019). Parental care and the evolution of terrestriality in frogs. Proc. R. Soc. B 286, 27-37. doi: 10.1098/rspb.2018.2737

Vági, B., Végvári, Z., Liker, A., Freckleton, R. P., and Székely, T. (2020). Climate and mating systems as drivers of global diversity of parental care in frogs. Glob. Ecol. Biogeogr. 29, 1373-1386. doi: 10.1111/geb.13113

Velo-Antón, G., García-París, M., Galán, P., and Cordero Rivera, A. (2007). The evolution of viviparity in holocene islands: ecological adaptation versus phylogenetic descent along the transition from aquatic to terrestrial environments. J. Zoolog. Syst. Evol. 45, 345-352. doi: 10.1111/j.1439-0469.2007. 00420.x

Wake, D. B., and Hanken, J. (2004). Direct development in the lungless salamanders: what are the consequences for developmental biology, evolution and phylogenesis? Int. J. Dev. Biol. 40, 859-869.

Wake, M. H. (1978). The reproductive biology of Eleutherodactylus jasperi (Amphibia, Anura, Leptodactylidae), with comments on the evolution of livebearing systems. J. Herpetol. 12, 121-133. doi: 10.2307/1563398

Wake, M. H. (1980). The reproductive biology of Nectophrynoides malcolmi (Amphibia: Bufonidae), with comments on the evolution of reproductive modes in the genus Nectophrynoides. Copeia 1980, 193-209. doi: 10.2307/ 1443998

Warkentin, K. M. (2011). Plasticity of hatching in amphibians: evolution, tradeoffs, cues and mechanisms. Integr. Comp. Biol. 51, 111-127. doi: 10.1093/icb/ icr046

Wells, K. D. (2007). The Ecology and Behavior of Amphibians. Chicago, IL: University of Chicago Press.

Werner, E. E. (1986). Amphibian metamorphosis: growth rate, predation risk, and the optimal size at transformation. Am. Nat. 128, 319-341. doi: 10.1086/284565

Werner, E. E., and Anholt, B. R. (1993). Ecological consequences of the trade-off between growth and mortality rates mediated by foraging activity. Am. Nat. 142, 242-272. doi: 10.1086/285537

Werner, E. E., and Gilliam, J. F. (1984). The ontogenetic niche and species interactions in size-structured populations. Annu. Rev. Ecol. Syst. 15, 393-425. doi: 10.1146/annurev.es.15.110184.002141

Werner, E. E., and Hall, D. J. (1988). Ontogenetic habitat shifts in bluegill: the foraging rate-predation risk trade-off. Ecology 69, 1352-1366. doi: 10.2307/ 1941633
Werner, E. E., Mittelbach, G. G., Hall, D. J., and Gilliam, J. F. (1983). Experimental tests of optimal habitat use in fish: the role of relative habitat profitability. Ecology 64, 1525-1539. doi: 10.2307/1937507

Whiteman, H. H. (1994). Evolution of facultative paedomorphosis in salamanders. Q. Rev. Biol. 69, 205-221. doi: 10.1086/418540

Wilbur, H. M. (1977a). Density-dependent aspects of growth and metamorphosis in Bufo americanus. Ecology 58, 196-200. doi: 10.2307/1935122

Wilbur, H. M. (1977b). Propagule size, number, and dispersion pattern in Ambystoma and Asclepias. Am. Nat. 111, 43-68. doi: 10.1086/283137

Wilbur, H. M. (1980). Complex life cycles. Annu. Rev. Ecol. Syst. 11, 67-93. doi: 10.1146/annurev.es.11.110180.000435

Wilbur, H. M., and Collins, J. P. (1973). Ecological aspects of amphibian metamorphosis: nonnormal distributions of competitive ability reflect selection for facultative metamorphosis. Science 182, 1305-1314. doi: 10.1126/science. 182.4119.1305

Winandy, L., Darnet, E., and Denoël, M. (2015). Amphibians forgo aquatic life in response to alien fish introduction. Anim. Behav. 109, 209-216. doi: 10.1016/j. anbehav.2015.08.018

Winemiller, K. O., and Rose, K. A. (1992). Patterns of life-history diversification in North American fishes: implications for population regulation. Can. J. Fish. Aquat. Sci. 49, 2196-2218. doi: 10.1139/f9 2-242

Wood, P. J., Greenwood, M. T., and Agnew, M. D. (2003). Pond biodiversity and habitat loss in the UK. Area 35, 206-216. doi: 10.1111/1475-4762.0 0249

Zhao, T., Wang, B., Shu, G., Li, C., and Jiang, J. (2018). Amphibian species contribute similarly to taxonomic, but not functional and phylogenetic diversity: inferences from amphibian biodiversity on Emei Mountain. Asian Herpetol. Res. 9, 110-118. doi: 10.16373/j.cnki.ahr.17 0079

Conflict of Interest: The authors declare that the research was conducted in the absence of any commercial or financial relationships that could be construed as a potential conflict of interest.

Publisher's Note: All claims expressed in this article are solely those of the authors and do not necessarily represent those of their affiliated organizations, or those of the publisher, the editors and the reviewers. Any product that may be evaluated in this article, or claim that may be made by its manufacturer, is not guaranteed or endorsed by the publisher.

Copyright (๑) 2022 Brooks and Kindsvater. This is an open-access article distributed under the terms of the Creative Commons Attribution License (CC BY). The use, distribution or reproduction in other forums is permitted, provided the original author(s) and the copyright owner(s) are credited and that the original publication in this journal is cited, in accordance with accepted academic practice. No use, distribution or reproduction is permitted which does not comply with these terms. 